\title{
Absence of linkage between familial neural tube defects and PAX3 gene
} S Chatkupt, F A Hol, Y Y Shugart, M P A Geurds, E S Stenroos,
M R Koenigsberger, B C J Hamel, W G Johnson, E C M Mariman

Departments of Neurosciences and Pediatrics, UMDNJNew Jersey Medical School, MSB-H-506, 185 South Orange Avenue, Newark, New Jersey 07103, USA

$S$ Chatkupt

M R Koenigsberger

Department of Human Genetics, University

Hospital Nijmegen,

Nijmegen,

The Netherlands

F A Hol

M P A Geurds

B C J Hame

E C M Mariman

Department of

Genetics and

Development,

Columbia University,

New York, USA

Y Y Shugart

Department of Neurology, UMDNJ-

Robert Wood Johnson

Medical School,

New Brunswick,

New Jersey, USA

E S Stenroos

W G Johnson

Correspondence to Dr Chatkupt.

Received 17 July 1994 Revised version accepted for publication

9 November 1994

\begin{abstract}
Neural tube defects (NTD) are among the most common and disabling birth defects. The aetiology of NTD is unknown and their genetics are complex. The majority of NTD cases are sporadic, isolated, nonsyndromic, and generally considered to be multifactorial in origin. Recently, PAX3 (formerly $\mathrm{HuP2}$, the human homologue of mouse Pax-3), on chromosome 2q35-37, was suggested as a candidate gene for NTD because mutations of $\mathrm{Pax}-3$ cause the mouse mutant Splotch $(S p)$, an animal model for human NTD. Mutations in PAX3 were also identified in patients with Waardenburg syndrome type 1 (WS1). At least eight patients with both WS1 and NTD have been described suggesting pleiotropy or a contiguous gene syndrome.

Seventeen US families and 14 Dutch families with more than one affected person with NTD were collected and 194 people (50 affected) from both data sets were genotyped using the PAX3 polymorphic marker. The data were analysed using affecteds only linkage analysis. The lod scores were -7.30 (US), -3.74 (Dutch), and $-11 \cdot 04$ (combined) at $\theta=0 \cdot 0$, under the assumption of the autosomal dominant model. For the recessive model, the lod scores were -3.30 (US), -1.46 (Dutch), and $-4 \cdot 76$ (combined) at $\theta=0 \cdot 0$.

Linkage between PAX3 and familial NTD was excluded to $9.9 \mathrm{cM}$ on either side of the gene for the dominant model and to $3.63 \mathrm{cM}$ on either side of the gene for the recessive model in the families studied. No evidence of heterogeneity was detected using the HOMOG program. Our data indicate that PAX3 is not a major gene for NTD.
\end{abstract}

( $(\mathcal{M}$ Med Genet 1995;32:200-204)

Neural tube defects (NTD) are among the most common birth defects and have been associated with certain syndromes and chromosome abnormalities (including trisomies 13 , 18 , and 21$)^{1}$ and an $\mathrm{X}$ linked condition. ${ }^{2-5}$ The majority of NTD cases are sporadic, isolated, non-syndromic, and generally considered to be multifactorial in origin with a heritability of about 70 to $80 \% .^{6}$ However, a number of familial cases have been documented implicating genetic susceptibility factors in familial NTD. ${ }^{7-12}$

The mouse mutant Splotch $(S p)$ has long been recognised as a model for human NTD. Splotch homozygotes develop spina bifida, meningocele, and exencephaly. ${ }^{13}$ Most mutants die in utero. Splotch heterozygotes have pigmentation defects resulting in white feet, tail tip, and belly patch. These pigmentation defects as well as deficiencies in neural crest derived tissues and cells (NCC), that is, spinal ganglia and Schwann cells, are caused by the failure of NCC to populate these regions sufficiently during development. ${ }^{1314}$ Mutations in the Pax-3 gene result in the $S p$ phenotype. ${ }^{15}$ The paired box containing genes, the Pax genes, encode for sequence specific DNA binding transcription factors that play a role in embryonic development. To date, nine pax genes, Pax 1-9, have been isolated. ${ }^{14}{ }^{16} \mathrm{Pax}-3$ is expressed in the neural tube, in the NCC, in the dermomyotome of the developing somites, in limb buds, and in the developing brain. ${ }^{14} 17$ The Pax-3 gene, located on mouse chromosome 1 , is homologous to the human PAX3 or formerly $\mathrm{HuP} 2$ gene at $2 \mathrm{q} 35-37 .{ }^{14}$ Mutations in PAX3 have been described in patients with Waardenburg syndrome type 1 (WS1), a syndrome consisting of pigmentary disturbances resulting from abnormalities related to NCC emigration, a pathogenesis similar to that of $S p$ mice. ${ }^{18-20}$ Reports of at least eight patients with both WS1 and NTD raise the possibility of pleiotropy or a contiguous gene syndrome. ${ }^{21-23}$ To test this hypothesis, we conducted linkage analysis on 31 NTD families using the PAX3 polymorphic marker.

\section{Patients and methods}

PATIENTS, FAMILY, AND CLINICAL EVALUATION Families from the United States were ascertained by referrals from spina bifida clinics, and by responses of patients to notices in patient newsletters. Our specific request was for families with more than one case of spina bifida cystica (SB) or other NTD. Syndromic or chromosome abnormality cases were excluded. Diagnoses were based on detailed clinical information from interviews by us, from direct review of the medical records (31 records), or from medical record review by physicians and nurses in the referring SB clinics. Information obtained for index and other cases included: family pedigree, number of affected cases in each family, sex, ethnic background, and birth dates of the cases, their mothers, and their fathers.

For the Dutch families, criteria for selection of cases and information obtained were similar. These families were selected in collaboration 
Neural tube defects and PAX 3 gene

201
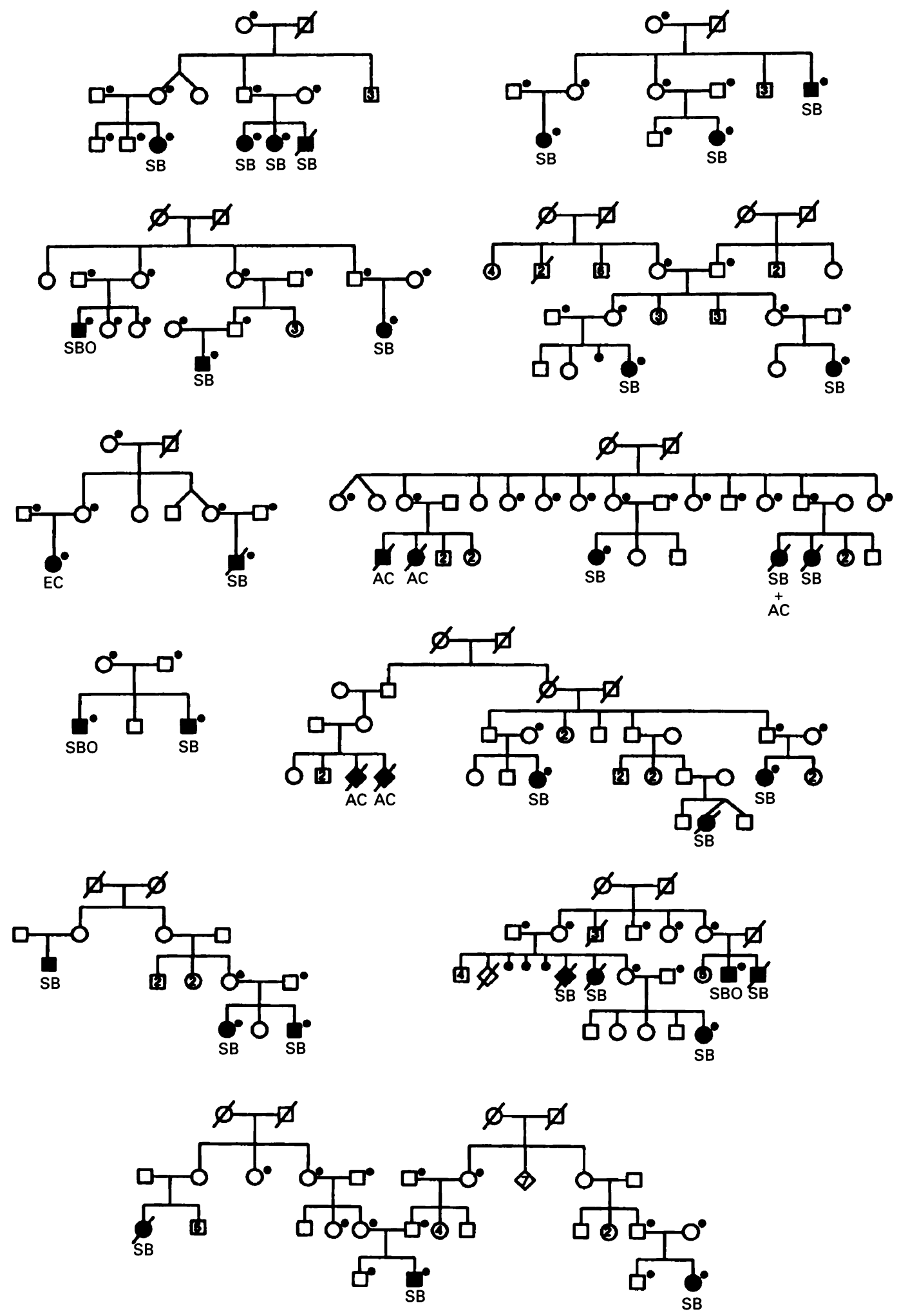

Pedigrees of all informative NTD families. Shaded squares and circles represent indicates a person who was indicates a person genotype. $A C=$ encephalocele, $S B=$ spine bifid cystic, and $S B O=$ spin bifid occult.
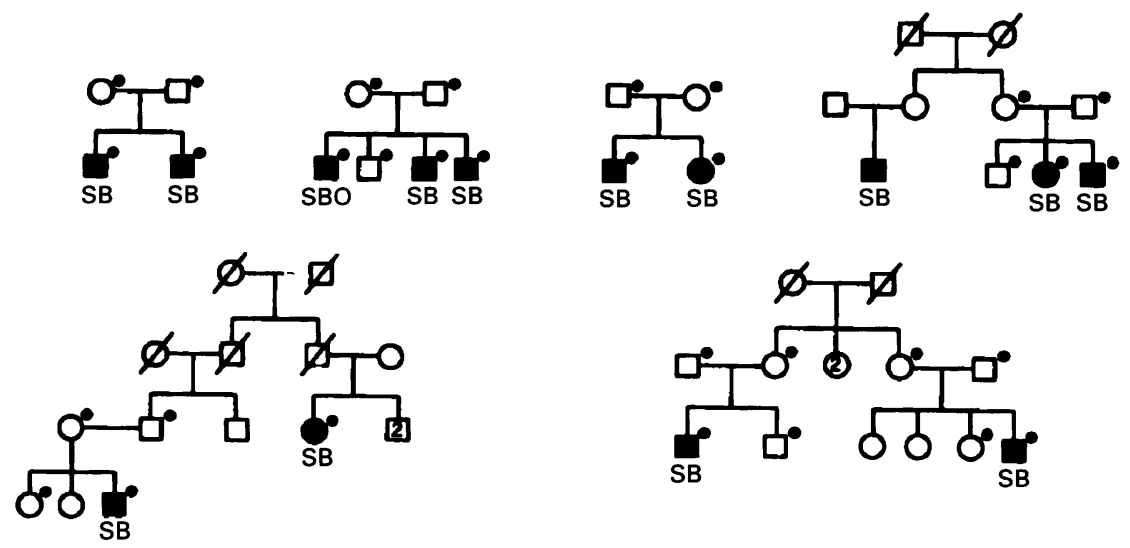

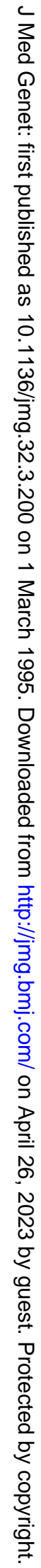


with the Dutch patient organisation BOSK and from the records of University Hospital Nijmegen.

DNA from 102 subjects in 17 US families and from 92 subjects in 14 Dutch families were collected. Twenty-nine living affected patients from US families had SB, and two additional people had spina bifida occulta (SBO). Seventeen living affected subjects from Dutch families had SB, two had SBO, and one had encephalocele (EC). DNA was not available from 13 patients with SB (US families) and 15 patients with $S B$, seven with anencephaly (AC), and two with SB and AC (Dutch families). Pedigrees of all informative families are shown in the figure. There were five families with sib pairs only (two of those were Hispanic).

Among the 17 US families, 14 were white with multiple ethnicities including British, Dutch, French, German, Irish, Italian, Norwegian, Russian, Scottish, and Swedish. Three families were Hispanic. All the Dutch families were white.

DNA METHOIIS AND POLYMORPHISM ANALYSIS Blood samples were collected after informed consent was obtained and their transformed cell lines we:e established. DNA was prepared from each transformed cell line by standard methods. $^{24}$ The short tandem repeat polymorphism (STRP) located on the $5^{\prime}$ side of exon 1 of the PAX 3 gene was used. ${ }^{25}$ We designed a new set of primers flanking the same repeat in order to reduce the size of the PCR products. This made it easier to separate the different alleles on acrylamide gel. Forward primer: 5'-AGTTGCTGAGGGCGGAGAAG$3^{\prime}$ and reverse primer: 5'-GAAATCACAAGAGGATAGAGGCT-3'. Product sizes were 192 to $218 \mathrm{bp}$. DNA was amplified by PCR using published conditions ${ }^{25}$ in a $25 \mu \mathrm{l}$ reaction

Table 1 Lod scores under dominant model, penetrance $=0.45$

\begin{tabular}{|c|c|c|c|c|c|c|c|}
\hline & \multicolumn{7}{|l|}{$\theta$} \\
\hline & 0.0 & 0.01 & 0.05 & 0.1 & $0 \cdot 2$ & $0 \cdot 3$ & 0.4 \\
\hline $\begin{array}{l}\text { US } \\
\text { Dutch } \\
\text { Sum }\end{array}$ & $\begin{array}{c}-7 \cdot 3 \\
-3 \cdot 74 \\
-11.04\end{array}$ & $\begin{array}{l}-5 \cdot 14 \\
-2 \cdot 10 \\
-7 \cdot 24\end{array}$ & $\begin{array}{l}-2.94 \\
-0.58 \\
-3.52\end{array}$ & $\begin{array}{l}-1.68 \\
-0.04 \\
-1.72\end{array}$ & $\begin{array}{r}-0.59 \\
0.24 \\
-0.35\end{array}$ & $\begin{array}{r}-0.20 \\
0.20 \\
0 \cdot 00\end{array}$ & $\begin{array}{r}-0.06 \\
0.10 \\
0.04\end{array}$ \\
\hline
\end{tabular}

Table 2 Lod scores under recessive model, penetrance $=0.45$

\begin{tabular}{|c|c|c|c|c|c|c|c|}
\hline & \multicolumn{7}{|l|}{$\theta$} \\
\hline & 0.0 & 0.01 & 0.05 & $0 \cdot 1$ & $0 \cdot 2$ & $0 \cdot 3$ & 0.4 \\
\hline $\begin{array}{l}\text { US } \\
\text { Dutch } \\
\text { Sum }\end{array}$ & $\begin{array}{l}-3.30 \\
-1.46 \\
-4.76\end{array}$ & $\begin{array}{l}-2.57 \\
-1.09 \\
-3.66\end{array}$ & $\begin{array}{l}-1 \cdot 16 \\
-0.31 \\
-1.47\end{array}$ & $\begin{array}{r}-0.45 \\
0.09 \\
-0.36\end{array}$ & $\begin{array}{l}0.02 \\
0 \cdot 28 \\
0 \cdot 30\end{array}$ & $\begin{array}{l}0 \cdot 08 \\
0 \cdot 21 \\
0 \cdot 29\end{array}$ & $\begin{array}{l}0.04 \\
0.09 \\
0.13\end{array}$ \\
\hline
\end{tabular}

Table 3 Lod scores under dominant model, penetrance $=0 \cdot 27$

\begin{tabular}{|c|c|c|c|c|c|c|c|}
\hline & \multicolumn{7}{|l|}{$\theta$} \\
\hline & 0.0 & 0.01 & 0.05 & 0.1 & 0.2 & 0.3 & 0.4 \\
\hline $\begin{array}{l}\text { US } \\
\text { Dutch } \\
\text { Sum }\end{array}$ & $\begin{array}{l}-6.21 \\
-3.01 \\
-9.22\end{array}$ & $\begin{array}{l}-4.57 \\
-1.88 \\
-6.45\end{array}$ & $\begin{array}{l}-2 \cdot 68 \\
-0.54 \\
-3 \cdot 22\end{array}$ & $\begin{array}{l}-1.57 \\
-0.02 \\
-1.59\end{array}$ & $\begin{array}{r}-0.56 \\
0.24 \\
-0.32\end{array}$ & $\begin{array}{r}-0.19 \\
0.20 \\
0.01\end{array}$ & $\begin{array}{r}-0.05 \\
0.09 \\
0.04\end{array}$ \\
\hline
\end{tabular}

mixture containing $20 \mathrm{ng}$ of genomic DNA, $10 \mathrm{mmol} / 1$ Tris-Cl, $1.5 \mathrm{mmol} / 1 \mathrm{MgCl}_{2}$, $50 \mathrm{mmol} / 1 \mathrm{KCl}, 200 \mu \mathrm{mol} / 1 \mathrm{dATP}, 200 \mu \mathrm{mol} / 1$ $\mathrm{dGTP}, \quad 200 \mu \mathrm{mol} / 1 \mathrm{dTTP}, \quad 2.5 \mu \mathrm{mol} / 1 \mathrm{dCTP}$, $25 \mathrm{nmol} / \mathrm{s}^{32} \mathrm{P}-\alpha$-dCTP, $15 \mathrm{pmol}$ of each primer, and 0.25 units of Taq DNA polymerase. PCR products were separated on $6 \%$ acrylamide $(19: 1$ bis) gels, and autoradiographically visualised by a 1 to 16 hour exposure to Kodak $\mathrm{X}$-AR film.

LINKAGE ANALYSIS OF PAX3 AND NTD

The incidence of $S B$ is $4 \cdot 3 / 10000$ live births in the US, and $1 / 1000$ live births for NTDs in the Netherlands. ${ }^{2627}$ The difference in incidence results from the fact that affected subjects in the US data only had SB and SBO, whereas affected subjects in the Dutch data had varieties of NTD: SB, AC, and EC. The penetrance for genetic cases of SB was 0.45 based on the published data, ${ }^{11}$ and for genetic cases of NTD was $0 \cdot 27$. The phenocopy frequency was based on the estimation that $50 \%$ of the cases are non-genetic. The analysis was also performed under the assumption of phenocopy rate of zero. Disease allele frequencies were calculated from disease incidence and penetrances.

Linkage analysis was performed using the LINKAGE computer package (version $5 \cdot 1)^{28}$ Because of the unclear mode of inheritance of SB and NTD, we performed analyses under the assumption of dominant and recessive models. Under the dominant assumption, the disease allele frequencies were estimated to be 0.00025 and 0.00088 for the US and the Dutch data respectively, and 0.022 and 0.042 for the US and the Dutch respectively under the recessive model. The affecteds only method was used in the linkage analysis by making the phenotype of unaffected family members unknown.

In order to assess the possible linkage of NTD to the PAX 3 gene, the marker PAX 3 was selected for genotyping. Allele frequencies for this marker used in the US data set were as published $^{25}$ (using control US population). For the Dutch data set, allele frequencies were calculated from 37 unrelated people (Dutch) selected from the same geographical areas as Dutch NTD families. The allele frequencies from the two populations were not significantly different.

\section{Results}

Two point lod scores were calculated for various recombination fractions assuming $\theta_{\mathrm{m}}=\theta_{\mathrm{f}}$, penetrance of 0.45 and autosomal dominant (table 1) or autosomal recessive models (table 2). Results for affecteds only analysis showed exclusion of linkage between familial NTD and the PAX 3 gene to $9.9 \mathrm{cM}$ on either side of the gene for the dominant model and to $3.63 \mathrm{cM}$ on either side of the gene for the recessive model in the present families. Two point lod scores were also calculated assuming penetrance of $0 \cdot 27$ (tables 3 and 4 ). The two point lod score assuming the phenocopy rate of zero showed similar results (data not shown). 
Table 4 Lod scores under recessive model, penetrance $=0.27$

\begin{tabular}{llllllll}
\hline & $\theta$ & & & & & & \\
\cline { 2 - 7 } & 0.0 & 0.01 & 0.05 & 0.1 & 0.2 & 0.3 & 0.4 \\
\hline US & -3.15 & -2.49 & -1.16 & -0.47 & 0.00 & 0.07 & 0.03 \\
Dutch & -1.11 & -0.84 & -0.22 & 0.11 & 0.27 & 0.20 & 0.08 \\
Sum & -4.26 & -3.33 & -1.38 & -0.36 & 0.27 & 0.27 & 0.11 \\
\hline
\end{tabular}

No evidence for genetic heterogeneity was detected using the HOMOG program ${ }^{29}$ (data not shown).

\section{Discussion}

The application of linkage analysis to disease which display complex traits carries several difficulties because of: (1) the uncertainty of mode of inheritance and penetrance, (2) the small family sizes, (3) the unclear phenotypes, and (4) genetic heterogeneity. ${ }^{30-32}$ However, the complex traits are among the most common human disorders and efforts should be made to unravel such problems. Linkage analysis has been used successfully to locate predisposing genes for complex traits such as familial Alzheimer's disease. ${ }^{33}$

Although NTDs have been considered to have multifactorial threshold inheritance with the phenotype depending upon an interaction between genetic and environmental factors, monogenic inheritance with a major contribution of environmental factors has been suggested. ${ }^{34}$ Another study ${ }^{35}$ in which SBO was included with SB and sacral agenesis supported autosomal dominant inheritance with segregation distortion similar in type to that seen with alleles at the $\mathrm{T}$ locus in the mouse. ${ }^{36}$ However, it is possible that a gene for NTD segregates in an autosomal recessive manner. ${ }^{37}$ In addition, autosomal recessive inheritance has been suggested for some families with anencephaly. ${ }^{3839}$ If there is a major gene segregating in NTD families either in an autosomal dominant or autosomal recessive manner, linkage analysis is likely to be able to locate such a gene.

Because the mode of inheritance and penetrance are uncertain, we analysed the data under the assumption of both autosomal dominant and autosomal recessive models. One of the worst potential model misspecifications is the misspecification of dominance ${ }^{40}$ and therefore the recessive model was also applied in our data. Assumption of a high penetrance may falsely generate exclusion of the linkage whereas a low penetrance approach may reduce the power to detect linkage. We carried out the analysis using a variety of parameters with different levels of penetrance: 0.45 and $0 \cdot 27$. Our result did not show evidence of linkage between familial NTD and this marker which is located within the PAX3 region itself.

SBO has been considered a variable expression of the SB gene. ${ }^{41-44}$ Radiography of the spine was not performed in the unaffected subjects in our series apart from two subjects from the US families and two from the Dutch family who had SBO detected on radiography of the spine performed for other medical reasons. Therefore the analysis was performed including SBO. However, because there were only four SBO in the data set, excluding them did not have significant influence on lod scores.

There has been concern regarding genetic heterogeneity based on the level of the defects (high level SB above T11 v low level SB) perhaps representing defects in neurulation versus canalisation ${ }^{45}$ However, this question remains controversial. ${ }^{46}$ It was also suggested that $\mathrm{AC}$ may be distinct from $\mathrm{SB}^{45}$ although both may occur in the same family and the occurrence rate of each type is increased in sibs of children affected by the other. ${ }^{47}$ In this respect, the same major gene is likely to contribute to different phenotypes. Nevertheless, if in fact different phenotypes such as SB and AC are caused by different loci, combining data may result in a false negative lod score. This is not the case in our series. All affected subjects in the US families had SB and SBO whereas the affected subjects in the Dutch data had varieties of NTD, SB, AC, and EC. However, only the patients with SB, SBO, and EC from the Dutch families were genotyped. Linkage was not detected in the US families with only SB, a result similar to that from the Dutch subset.

Such "exclusion" results must be interpreted cautiously, especially since the phenocopy rate is only approximate. However, our data exclude $\mathrm{PAX} 3$ as a major gene in the present families with familial NTD and familial SB under the assumption of the above parameters.

The cooperation of the families, of the staff of spina bifida clinics in the United States, and of the Dutch Patient Organisation BOSK, The Netherlands, is gratefully acknowledged. The support of NIH grants 2-S07-RR05393 (SC), R29NS29893 (SC, WGI), and HG00008(YYS), the Foundation NS29893 (SC, WGJ), and HG00008(YYS), the Foundation of UMDNJ (SC), the March of Dimes Birth Defects Foundation \#8-FY91-0939 (SC), and the "Prinses Beatrix Fonds" 93-005
(ECMM) are gratefully acknowledged. We also thank Prof Dr H H Ropers for helpful discussions and Dr John Horan and Anindita Sarangi for technical assistance.

1 Khoury MJ, Erickson JD, James LM. Etiological heterogeneity of neural tube defects: clues from epidemiology. Am $\mathcal{F}$ Epidemiol 1982;115:538-48.

2 Baraitser M, Burn J. Brief clinical report: neural tube defects as an X-linked condition. Am $\mathcal{F}$ Med Genet 1984;17:383-5.

3 Toriello HV. Report of a kindred with X-linked anencephaly/ spina bifida. Am $\mathcal{F}$ Med Genet 1984;19:411-12.

4 Toriello HV, Higgins JV. X-linked midline defects. Am $\mathcal{F}$ Med Genet 1985;21:143-6.

5 Jenssen O, Arnason A, Gunnarsdottir H, Petursdottir I, Fossdal R, Hreidarsson S. A family showing apparent $\mathrm{X}$ linked inheritance of both anencephaly and spina bifida. f Med Genet 1988;25:227-9.

6 Bodmer WF, Cavalli-Sforza LL. Genetics, evolution, and man. San Francisco: Freeman, 1976.

7 Carter CO, David PA, Laurence KM. A family study of major central nervous system malformations in South Wales. F Med Genet 1968;5:81-106.

8 Nevin NC, Johnston WP. A family study of spina bifida and anencephalus in Belfast, Northern Ireland (1964 to 1968). F Med Genet 1980;17:203-11.

9 Williamson EM. Incidence and family aggregation of major congenital malformations of central nervous system. $\mathcal{F}$ Med Genet 1965;2:161-72.

10 Mariman ECM, Hamel BCJ. Sex ratio of affected and transmitting members of multiple cases of neural tube defects. $\mathcal{F}$ Med Genet 1992;29:695-8.

11 Chatkupt S, Lucek PR, Koenigsberger MR, Johnson WG. Parental sex effect in spina bifida: a role for genomic imprinting? Am f Med Genet 1992;44:508-12.

12 Chatkupt S, Skurnick JH, Jaggi M, Mitruka K, Koenigsberger MR, Johnson WG. Study of genetics, epidemiology, and vitamin usage in familial spina bifida in the United and vitamin usage in familial spina bifida in the

13 Moase CE, Trasler DG. Splotch locus mouse mutants: models for neural tube defects and Waardenburg syndrome type 1 in humans. $\mathcal{F}$ Med Genet 1992;29:145-51.

14 Chalepakis G, Stoykova A, Wijnholds J, Tramblay P, Gruss $P$. Pax gene regulators in the developing nervous system. P. Pax gene regulators in the
$\mathcal{f}$ Neurobiol 1993;24:1367-84.

15 Epstein DJ, Vekemans M, Gros P. splotch $\left(S p^{2 H}\right)$, a mutation affecting development of the mouse neural tube, shows a 
deletion within the paired homeodomain of Pax-3. Cell 1991;67:767-74.

16 Stapleton P, Weith A, Urbanek P, Kozmik Z, Busslinge $M$. Chromosomal localization of several $P A X$ genes and cloning of a novel family member, $P A X-9$. Nature Genet 1993;3:292-7.

17 Goulding MD, Chalepakis G, Deutsch U, Erselius J, Gruss $P$, Pax-3, a novel murine DNA binding protein expressed during early neurogenesis. $E M B O \mathcal{F} 1991 ; 10: 1135-47$.

18 Baldwin CT, Hoth CF, Amos JA, O da-Silva E, Milunsky A. An exonic mutation in the $H u P 2$ paired domain gene causes Waardenburg's syndrome. Nature 1992;355:637-8

19 Morell R, Friedman TB, Moeljopawiro S, Hartono, Seowito, Asher Jr JH. A frameshift mutation in the HuP2 paired domain of the probable human homolog of murine Pax3 is responsible for Waardenburg syndrome type 1 in an Indonesian family. Hum Mol Genet 1992;1:243-7.

20 Tassabehii M, Read AP, Newton VE, et al. Waardenburg's syndrome patients have mutations in the human homologue of the Pax-3 paired box gene. Nature 1992;355:635-6.

21 Carezani-Gavin M, Clarren SK, Steege T. Waardenburg syndrome associated with myelomeningocele. $A m f \mathrm{Med}$ Genet 1992;42:135-6.

22 Chatkupt S, Chatkupt S, Johnson WG. Waardenburg syndrome and myelomeningocele in a family. $f$ Med Genet

23 Moline ML, Sandlin C. Waardenburg syndrome and meningomyelocele. Am $\mathcal{F}$ Med Genet 1993;47:126.

24 Sambrook J, Fritsch EF, Maniatis T. Molecular cloning. A laboratory manual. 2nd ed. Cold Spring Harbor, NY: Cold Spring Harbor Laboratory Press, 1989.

25 Wilcox ER, Rivolta MN, Ploplis B, Potterf SB, Fex J. The PAX3 gene is mapped to human chromosome 2 togethe with a highly informative CA dinucleotide repeat. Hum Mol Genet 1992;1:215.

26 Edmonds LD, James LM. Temporal trends in the prevalence of congenital malformations at birth based on the birth defects monitoring program, United States, 1979-1987. MMWR 1990;39(SS-4):19-23.

27 Verheij JBGM, Edens M, Cornel MC, Groothoff JW, Ten Kate LP. Incidentie en prevalentie van genetisch bepaalde Kate LP. Incidentie en prevalentie van genetisch bepaalde Tjidschr Geneeskd 1994;138:71-7.

28 Lathrop GM, Lalouel JM, Julier C, Ott J. Strategies for mutilocus linkage analysis in humans. Proc Natl Acad Sci

29 Ott J. Analysis of human genetic linkage. Baltimore: Johns Hopkins University Press, 1991.
30 Lander ES. Mapping complex genetic traits in humans. In: Davies KE, ed. Genome analysis: a practical approach. Oxis: IRL Press, 1989:171-91.

31 Ott J. Cutting a Gordian knot in the linkage analysis of complex human traits. Am f Med Genet 1990;46:219-21. 32 Risch N. Genetic linkage and complex diseases with special reference to psychiatric disorders. Genet Epidemiol 1990; $7: 3-16$

33 Pericak-Vance MA, Bebout JL, Gaskell PC Jr, et al. Linkage studies in familial Alzheimer's disease: evidence for chromosome 19 linkage. Am f Hum Genet 1991;48:1034-50.

34 Demenias M, LeMerrer M, Briard ML, Elston RC. Neural tube defects in France: segregation analysis. $A m \mathcal{7} M e d$ Genet 1982;11:287-98.

35 Fellous M, Boue J, Malbrunot C, et al. A five-generation family with sacral agenesis and spina bifida: possible similarity with the mouse T-locus. Am f Med Genet 1982;12: 465-87.

36 Bennett D. The T-locus in the mouse. Cell 1975;6:441-54.

7 Lorber J. The family history of spina bifida cystica. Pediatrics 1965;35:589-95.

38 Farag TI, Teebi AS, Al Awadi SA. Nonsyndromal anencephaly: possible autosomal recessive variant. $A m \mathcal{f} M e d$ Genet 1986;24:461-4.

39 Shaffer LG, Marazita ML, Bodurtha J, Newlin A, Nance WE. Evidence for a major gene in familial anencephaly. Am 7 Med Genet 1990;36:97-101.

40 Clerget-Darpoux F, Bonaiti-Pellié C, Hochez J. Effects of misspecifying genetic parameters in lod score analysis. Biometrics 1986;42:393-9.

41 Carter CO, Evans KA, Till K. Spinal dysraphism: genetic relation to neural tube malformations. F Med Genet 1976; 13:343-50.

42 Fineman RM, Jorde LB, Martin RA, Hasstedt SJ, Wing SD, Walker ML. Spinal dysraphia as an autosomal dominant defect in four families. Am f Med Genet 1982;12:457-64.

43 Campbell LR, Dayton DH, Sohal GS. Neural tube defects: a review of human and animal studies on the etiology of neural tube defects. Teratology 1986;34:171-87.

44 Sever LE. Spinal anomalies and neural tube defects. $A m \mathcal{F}$ Med Genet 1983;15:343-5.

45 Toriello HV, Higgins JV. Possible causal heterogeneity in spina bifida cystica. Am $\mathcal{F}$ Med Genet Suppl. 1985;21:13-20.

46 Seller MJ. Neural tube defects: are neurulation and canalization forms causally distinct. Am $₹$ Med Genet 1990 35:394-6.

47 Nora JJ, Fraser FC. Medical genetics: principles and practice. 2nd ed. Philadephia: Lea \& Febiger, 1981:308. 